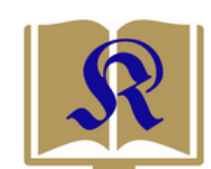

KURIOS

\title{
Fungsi Gereja Sebagai Entrepreneurship Sosial dalam Masyarakat Majemuk
}

\author{
Erman S. Saragih \\ Institut Agama Kristen Negeri Tarutung \\ ermansaragih9@gmail.com
}

\begin{abstract}
There is a tendency that the church has not been maximal in carrying out its social functions when viewed from the issue of a pluralistic community context. The church must actively transform the deacon, specifically alleviating the social problems surrounded. This study aimed to describe the model of transformation deaconal mission into the form of Christian entrepreneurs. By using literature review and descriptive methods, the conclusions obtained is: The church must be able to foster a sense of solidarity starting from inside the church to outside through the economic empowerment of her people.
\end{abstract}

\begin{abstract}
Abstrak
Ada kecenderungan bahwa gereja belum maksimal dalam menjalankan fungsi sosialnya ketika ditinjau dari persoalan konteks masyarakat majemuk. Gereja harus giat bertransformasi diakonia, secara khusus pengentasan masalah sosial yang berada disekitarnya. Kajian ini bertujuan untuk mendeskripsikan model transformasi misiologis diakonial dalam bentuk entrepreneur kristiani. Dengan menggunakan kajian literatur dan metode deskriptif, maka kesimpulan yang diperoleh adalah: Gereja harus dapat menumbuhkan rasa solidaritas dimulai dari jemaat hingga ke luar gereja melalui pemberdayaan ekonomi umat.
\end{abstract}

Article History

Submit:

22 January 2019

Revised:

05 April 2019 Accepted:

22 April 2019

Keywords (kata kunci):

Church; deacon; entrepreneur; social entrepreneurship; entrepreneur sosial; gereja; diakonia

\section{Pendahuluan}

Indonesia dikenal sebagai bangsa yang menganut ragam agama yang dibingkai dalam sila pertama Pancasila ke-Tuhan-an yang Maha Esa. Gereja merupakan salah satu dari ragam keagamaan serta mengakui Tuhan itu Esa. Oleh sebab itu gereja memiliki tanggungjawab dalam pembangunan, sebagai eksistensi moral yang melek pada persoalan sosial (Mat. 25:3146). Spiritual sejati dapat terwujud dalam kehidupan sosial, budaya, ekonomi dan politik. Gereja merupakan wujud kerajaan Allah di bumi dan juga sebagai pelaku injil; damai sejahtera yang nyata di tengah-tengah masyarakat (Luk. 10:25-37). Namun dalam mewujudkan tugas dan tanggung jawab tersebut, sudah pasti ada tantangan. Adapun tantangan gereja secara realita dilihat dari internal maupun eksternal. Tantangan internal; 
menekankan aspek kelembagaan dan mengabaikan persekutuan, sibuk dengan pembenahan gedung dan urusan organisasi, serta melupakan pembinaan iman.

Sering sekelompok orang di dalam gereja terjebak untuk menganggap dirinya lebih baik dan lebih benar daripada kelompok lain. Menurut F. Nanuru gereja belum maksimal dalam menjalankan fungsi sosialnya ketika berhadapan dengan persoalan kemiskinan, penindasan, krisis ekologi, dan sebagainya, karena perjuangannya masih terbungkus dalam bingkai religiusitasnya sebagai agama. Juga, dalam penelitiannya tentang keprihatinan sosial gereja injili, khususnya terhadap masalah kemiskinan di dua kota besar Jakarta dan Bandung, mengungkapkan bahwa sekitar 20-27\% dari seluruh responden telah mengalokasi dana untuk urusan sosial dan itu dilakukan 1-4 kali per tahun, dan hal itu dilakukan secara seremonial, maksudnya dilakukan pada saat perayaan-perayaan gerejawi seperti Paskah, Natal atau acara tertentu. ${ }^{1}$ Sekaitan dengan masalah ini mantan ephorus Gereja Kristen Protestan Simalungun (GKPS) juga berpendapat fungsi diakonia beberapa gereja protestan sudah mengalami pergeseran dari tujuan semula. Pelayanan diakonia cenderung secara seremonial, mengarah ke dalam dan kurang berdampak keluar. Seharusnya gereja dalam taraf usia sudah selesai dengan perosalan-persoalan internalnya dan semakin maju dalam dukungan perwujudan kepedulian lingkungan, keadilan dan kesejateraan bersama.

Perwujudan tanggung jawab gereja dalam penaggulangan masalah sosial benar mengalami tantangan globalisasi, saat ini dikenal dengan Era Revolusi Industri 4.0 dan pasti berdampak langsung pada sosial gereja secara personal dan masif. Menurut Menko Perekonomian, Darmin Nasution arus globalisasi sudah tidak bisa terbendung lagi dan pola ekonomi akan beralih kepada penekanan pada digital (era revolusi industri 4.1). Perubahan ini bisa saja berdampak positif bagi gereja yang mempersiapkan diri tetapi akan memperbesar peluang masalah kepada jemaat jika gereja abai dan menutup diri dalam religiusitasnya. Tantangan lainnya secara eksternal bagi gereja ialah materialisme, pola hidup serba cepat (instan), munculnya berbagai aliran dalam kekristenan.

Gereja merupakan bagian dari masyarakat majemuk seharusnya tidak kehilangan jati diri dalam tugas dan panggilan (Mat. 28:19-20). Bukankah Kristus datang bagi mereka yang lemah, miskin, dan kelaparan (Mat 4:23; 8:17)? Dalam hal ini Darwin mengemukan bahwa Gereja saat ini harus mempersiapkan jemaat menjadi kristen personal yang siap dalam berbagai arus perubahan zaman, dan bukan kristen kolektif. ${ }^{2}$ Tidak heran jika di gereja timbul kelompok individu antara kapitalis, kaum ilmuan, dan rohaniawan. Ini juga merupakan persoalan yang serius pada jemaat saat ini disamping masalah ekonomi. Kebijakan pemerintah yang tidak menentu, pertumbuhan penduduk yang semakin tinggi dan lowongan pekerjaan yang semakin sulit. Hal-hal seperti inilah salah satu faktor yang menjadi penyebab timbulnya kesenjangan sosial.

Salah satu contoh kasus yang diperoleh dari surat kabar harian Kompas, faktor pendorong anak-anak turun kejalan adalah alasan ekonomi sehingga mereka harus mencari

${ }^{1}$ Ricardo F Nanuru and Lomas Beatris Limpong, “Lomas Beatris Limpong 2,” Jurnal UNIERA 3, no. 1 (2014): 51-60.

${ }^{2}$ Darwin Lumbantobing, Teologi Di Pasar Bebas (Pematang Siantar: L. SAPA, 2010), 102. 
uang. Persoalan gelandangan pengangguran terkhusus anak jalanan adalah minimnya pemenuhan hak anak, baik oleh orang tua maupun pemerintah. Alasan orang tua, mayoritas biaya sekolah yang sangat tinggi. Anak yang bekerja di jalan atau yang biasa disebut "anak jalanan" bukan sekadar realita sosial dampak dari kemiskinan atau peniadaan asuh layak dari orang tua mereka, tetapi lebih dari itu. Realita sosial anak jalanan ini mengungkap sistem sosial disorganis dari suatu organisasi besar yang bernama Negara. Mereka mengemis di siang hari. Malam pun mereka berkeliaran. Kalau mereka ditangkap Tim Penertiban untuk "dibina", sebentar kemudian sudah muncul lagi di jalanan. Tempat-tempat rehabilitasi, maupun pusat pelatihan keterampilan remaja milik pemerintah, belum mampu menjawab persoalan yang ada. Karena pertambahan Anak Jalanan setiap tahun melebihi kemampuan pemerintah menanggulanginya. Sehingga dibutuhkan insiatif gereja, atau lembaga tertentu untuk mengambil bagian dalam masalah itu.

Yesus sangat peka dalam kasus seperti ini, Ia tampil beda, Ia memiliki rasa belas kasihan yang besar. Ia juru selamat yang beda; bukan pemenang, malah mati secara hina. Ia mengubah mindset orang tentang keselamatan (Mark. 6:30-34; 53-56). Keselamatan itu bukan soal nanti setelah mati. Keselamatan itu nyata, kini dan di sini; yang lapar dikenyangkan, yang buta dimelekkan, yang sakit disembuhkan, yang mati dihidupkan. Yesus mengubah mindset orang tentang kekayaan, kehormatan dan kemiskinan; persembahan janda miskin (Mrk. 12:1-4). Ia juga jelas berani ambil risiko; ditolak, dibunuh bahkan secara hina.

Persepsi tentang ikon gereja yang misioner juga dinilai dari hubungannya yang realistis dengan masyarakat secara umum. Gereja adalah kepunyaan Allah, yang sudah ditebus dengan harga yang tidak ternilai harganya, sehingga gereja bertanggungjawab mengindahkannya dalam konteks sosialnya masing-masing. Lebih lanjut, Robert (2004: 49) dalam membahas pemikiran Eka Darmaputera menyatakan bahwa "gereja adalah alat, bukan tujuan." Hal ini berarti bahwa hakikat keberadaan gereja adalah bahwa gereja haruslah menjadi alat yang harus digunakan untuk mensejaterahkan manusia. Gereja-gereja dituntut untuk mampu menjadi mediasi dan menjawab persoalan-persoalan yang menghambat kesejahteraan bersama. Damai itu harus dinikmati secara adil merata. Oleh sebab itu gereja dalam proses pengentasan kesenjangan sosial dalam komunitas secara personal dan sosial harus dikedepankan. Gereja bukan wadah eksklusif, melainkan wadah transformasi praksis iman sebagai proses perwujudan damai sejahtera bersama.

Pembahasan tentang gereja sebagai entrepreneur sosial merupakan hal yang penting, dan belum mendapatkan porsi yang memadai dalam konteks berteologi di Indonesia. Selama ini pembahasan gereja yang berkaitan dengan sosial dalam bentuk penelitian jurnal hanya beberapa, seperti yang dilakukan oleh Yushak Soesilo tentang protipe gereja mula-mula yang melakukan aksi sosial. $^{3}$ Selain itu ada pelayanan diakonia dalam hal pengentasan

\footnotetext{
${ }^{3}$ Yushak Soesilo, "Pentakostalisme Dan Aksi Sosial: Analisis Struktural Kisah Para Rasul 2 : 41-47," Dunamis : Jurnal Teologi dan Pendidikan Kristiani 2, no. 2 (2018): 136-151, http://sttintheos.ac.id/ejournal/index.php/dunamis/article/view/172/134.
} 
kemiskinan. ${ }^{4}$ Tema gereja dan entrepreneurship yang terkini dibahas oleh Sabaria Zega, yang menekankan pentingnya bagi hamba Tuhan untuk memahami entrepreneurship dari konteks biblical. ${ }^{5}$ Pembahasan pada artikel ini menekankan sisi gereja dengan fungsi entrepreneurship tersebut, sehingga penting untuk dipahami oleh gereja.

Dalam sejarah entrepreneur merupakan sebuah istilah yang muncul dalam situasi keruetan atas masalah-masalah yang tidak mampu diselesaikan dengan metode diakoni yang sifatnya tradisional. Tantangan gereja berbeda sesuai dengan koteks zamannya sehingga perlu dilakukan transformasi gereja dalam bidang diakonia. Dukungan dari pihak pemerintah, swasta dan secara khusus lembaga induk gereja juga bermanfaat untuk pencapaian maksimal. Sosial entrepreneurship hadir bukan untuk mengutamakan profit, melainkan pemberdayaan warga jemaat maupun lingkungan untuk menanamkan nilai-nilai keadilan, kesejahteraan, dan keagungan yang tak tergantikan dengan materi, sesuai dengan pesan spiritual entrepreneurship.

Dengan demikian tak dapat dihindari bahwa pembicaraan tentang bisnis dan iman Kristen merupakan tugas penting dan menarik untuk distudikan dari saat ke saat. Paling tidak dalam proses-proses refleksi ini, gereja semakin terbuka dan terukur dalam peran penemuan model/pola kehadiran gereja selama ini, dan sekaligus menjadi titik tolak bagi kehadiran gereja yang lebih relevan dalam menjawab konteks pelayanan gereja yang terus berubah. Berkaitan dengan uraian yang dikemukakan di atas, maka tujuan dari tulisan ini adalah mengingatkan bahwa kehadiran gereja dalam masyarakat majemuk adalah untuk memberitakan kabar kesukaan Allah, yang berelevansi pada keadilan, kesejahteraan tanpa batasan apapun, melalui pendekatan entrepreneur sosial berbasis spritual kekristenan.

\section{Metodologi}

Penelitian dilakukan dengan analisis deskripsi kualitatif, yaitu studi literatur dari yang dibutuhkan sesuai dengan latar belakang masalah dan tujuan penelitian. Data primer diperoleh dari hasil penelitian dalam bentuk jurnal, sedangkan data pendukungnya dari beberapa kajian buku-buku teologi dan entrepreneur social yang relevan dengan topik bahasan penelitian ini. Setelah data terkumpul, maka analisa reduksi data dilakukan untuk diintepretasi dan menghasilkan sintesa atau hasil penelitian.

Fundamen untuk beranjak kepada pemahaman gereja yang esensi yaitu mengerti etimologinya, yang tentunya hal tersebut melalui proses yang panjang dan untuk diterima oleh lapisan masyarakat kekristenan. Jika konsep dasar sudah salah maka sia-sialah usaha, sebab tolok ukur yang dipergunakan untuk memahami marwah gereja tidak tepat. Donald Guthrie mengemukakan bahwa gereja bukanlah suatu organisasi melainkan sekolompok orang yang dianggap oleh Yesus sebagai milikNya yang telah diajar, dan diutus untuk memperluas

\footnotetext{
${ }^{4}$ Mariani Febriana, "IMPLEMENTASI KEPEDULIAN SOSIAL GEREJA UNTUK MENOLONG MERETAS ANGKA KEMISKINAN,” Jurnal Theologi Aletheia 16, no. 7 (2014): 45-69, http://sttaletheia.ac.id/wp-content/uploads/2014/10/Pietas-dan-Caritas.pdf.

${ }^{5}$ Sabaria Zega, "Pentingnya Memahami Entrepreneurship Secara Biblikal Bagi Hamba Tuhan," KHARISMATA: Jurnal Teologi Pantekosta 1, no. 2 (2019): 118-132, http://www.stajember.ac.id/index.php/kharismata.
} 
kerajaanNya. ${ }^{6}$ Ekklesia merupakan bahasa Yunani yang mengacu kepada pengertian gaya hidup personal yang feminis, dengan maksud ia merupakan bagian dari covenant Kristus (Why.21:9). Oleh sebab itu gereja bukanlah gedung, dan organisasinya tetapi kiria (jemaat) milikNya. Berdasarkan uraian tersebut maka antara gereja dan jemaat merupakan sinonim, yang mengacu kepada personalnya.

Hubungan gereja dengan negara bersifat setara dan saling bekerja sama, bukan yang satu menguasai yang lain (1 Pet. 2:16). Gereja perlu bersikap kritis terhadap negara karena realita menunjukkan ada dua kemungkinan: Gereja semakin tersingkir dan tidak mempunyai pengaruh terhadap kehidupan masyarakat; Gereja cenderung mengikuti saja kebijakan negara sehingga makin kaburlah pemahaman mengenai misinya. Itu berarti gereja sudah menjadi serupa dengan dunia ini (Rm.12:1).

Kemajemukan menuntut orang Kristen di Indonesia untuk hidup berdampingan dengan penganut agama/kepercayaan lain, membina sikap toleransi dan saling menghargai. Tentang kemajemukan agama, buku "Iman Sesamaku dan Imanku" menyebut ada tiga sikap dalam komunitas Kristen, yaitu sebagai berikut:

Eksklusif: kebenaran dan keselamatan hanya ada melalui Kristus; Inklusif: meyakini bahwa Kristus juga hadir serta bekerja di kalangan mereka yang mungkin tidak mengenal Kristus secara pribadi; Pluralis: dipahami sebagai semangat untuk menghargai keyakinan agama sendiri sekaligus dengan menghormati keyakinan agama lain. Penganut agama lain tidak dilihat sebagai musuh, lawan, atau saingan. Sebaliknya, mereka adalah kawan sekerja, saudara, sesama yang memiliki tujuan yang sama, yakni kesejahteraan manusia dan alam ciptaan Allah. ${ }^{7}$

Beberapa Gereja sudah melakukan pelayanan diakoni dengan dasar Alkitab memaksimalkan talenta yang ada, seperti katolik dan juga protestan di Jerman, Singapura, Philipina dalam bentuk usaha bidang pendidikan, kesehatan, perkebunan, perhotelan dan pemberdayaan sosial dimana keuntungan digunakan untuk pelayanan yang sifatnya ke dalam ketimbang keluar. Mach Webbert mengemukakan bahwa pada masa kini gereja protestan sudah membuat area pendidikan, kesehatan, sosial ekonomi tetapi perlu dilihat spirit protestan itu adalah kapitalis dan dibalik itu sumbangsih reformasi adalah demokrasi dan Hak Azasi Manusia.

Pada era misi jerman, Huria Kristen Batak Protestan (HKBP) banyak mendirikan sekolahsekolah yang arahnya membuat ekonomi warga jemaat konteksnya seperti sekolah partukangan, sekolah keputrian, sekolah guru huria, dan sekolah kesehatan. Prinsipnya semua bagaimana warga jemaat mandiri. Analoginya bukan ikan yang diberikan, melainkan joran pancing agar dapat memancing ikan.

\section{Entrepreneurship Sosial}

Wirausaha (entrepreneurship), sebenarnya diambil dari kata Prancis, entreprende, yang berakar dari bahasa Jerman unternehmen, yang berarti "melaksanakan" (to undertake). Kata ini mulai dipopulerkan di Prancis, pada saat perang, untuk menunjuk pada kegiatan-kegiatan yang berbahaya dan penuh risiko, seperti membangun jembatan militer, pelabuhan, dan

\footnotetext{
${ }^{6}$ Donald Guthrie, Teologi Perjanjian Baru 3 (Jakarta: BPK Gunung Mulia, 1996), 34.

${ }^{7}$ World Council Of Churches, Iman Sesamaku Dan Imanku (Jakarta: BPK Gunung Mulia, n.d.).
} 
sejenisnya. Dengan demikian, orang yang melaksanakan pekerjaan ini membawa dua hal sekaligus: pengharapan dan pekerjaan. Dari situ, para ekonom Prancis memperluas maknanya menjadi: orang yang melakukan pekerjaan berbahaya dan berisiko untuk melakukan sebuah inovasi. ${ }^{8}$ Certo \& Miller mengemukakan bahwa memahami sosial entrepreneur sebagai misi dari nilai sosial dengan profit sebagai efek tidak langsung, dengan melakukan kegiatan sosial dengan mendapat profit kemudian mendistribusikannya sebagai upaya penciptaan nilai sosial. $^{9}$

Ada begitu banyak konsep yang berkembang dalam dunia entrepreneur dan entrepreneurship, Hagen (1962) secara sederhana menegaskan bahwa entrepreneurship adalah "human input into innovation". Semua masukan oleh manusia yang bersifat inovatif dalam bidang apapun mencerminkan entrepreneurship. Inovasi akan menghadirkan orangorang yang kreatif dalam menjalankan tugas-tugasnya. Tugas kreatif akan menghasilkan nilai dalam konteks organisasi. Nilai akan diaplikasikan dalam proses mengerjakan sesuatu yang baru dan berbeda dalam lingkungan sekitar sehingga terjadinya perubahan. Social entrepreneurshipas an activity that provides impetus to the social sector by creating and sustaining social value, recognizing and relentlessly pursuing new opportunities to serve the social mission, by engaging in a process of continuous innovation and adaptation, by acting boldly despite limited resources, and by exhibiting accountability to the constituencies served. (Dees, 2000).

Berkaitan dengan itu maka dideskripsikan hal-hal umum berkaitan dengan entrepreneur dan entrepreneurship sebagai berikut modal dan model dalam praktek kewirausahaan di atas berkembang dari waktu ke waktu dan telah memasuki berbagai ranah penelitian seperti yang ditemukan dalam beberapa penelitian. Entrepreneur adalah seorang pencipta, perancang, perencana, perantara dan pelayan (Seseorang yang memiliki Sifat-Sikap-Prilaku 5P). Entrepreneur digunakan untuk menggambarkan Sifat dan Sikap Allah sebagai seorang Creator. Merujuk pada Prilaku kerja orang-orang yang dipilih Allah sebagai perantara umat dengan-Nya dan diperlengkapi dengan keahlian untuk merancangbangun berbagai pekerjaan.

Mindset entrepreneur wujudnya adalah keberanian. Berani beda, berani ambil risiko, berani mengubah mindset. Bagi dia, tak ada halangan. Yang ada hanya tantangan. Tak ada kata mundur, hanya karena kata orang. Ia justru beda, karena itu ia akan maju terus. Termasuk kalau risikonya kehilangan harta yang paling berharga. Memahami konsep entrepreneur secara terbuka, dapat dikatakan bahwa seorang entrepreneur memiliki ciri-ciri khusus yang unik. Menurut Ciputra, ada tiga ciri penting dalam diri seorang wirausaha (real entrepreneur), yaitu : (1) Penciptaan peluang opportunity creating; (2) Melakukan inovasi innovating; dan (3) Mengambil resiko yang terukur calculated risk taking. Selanjutkan dikatakan bahwa

\footnotetext{
${ }^{8}$ Wee-Liang Tan, John Williams, and Teck-Meng Tan, "Defining 'Social' in Social Entrepreneurship: Altruism and Entrepreneurship,” International Entrepreneurship and Management Journal (2005): 353-365.

${ }^{9}$ Atu Bagus Wiguna, "Social Entrepreneur Dan Socio-Entrepreneur: Tinjau Dengan Perspektif Ekonomi Dan Sosial," Jurnal Ilmiah (2013).
} 
wirausahawan atau entrepreneur adalah mereka yang memiliki keandalan mengubah sampah menjadi emas. ${ }^{10}$

Nicholls mengatakan secara akademis, konsep social entrepreneurship telah dikembangkan di universitas-universitas salah satunya universitas yang ada di Inggris, seperti Skoll Center for Social Entrepreneurship. Contoh praktik social entrepreneurship, terdapat pada yayasan yang sudah mengglobal, yang secara khusus mencari para social entrepreneur di berbagai belahan dunia untuk membina dan memberikan dananya bagi para penggerak perubahan social yakni Ashoka Foundation. ${ }^{11}$

Dari studi tersebut, didapat proposisi yakni untuk membedakan kegiatan organisasi sosial nirlaba seperti pada organisasi-organisasi tersebut ialah penciptaan kemandirian finansial dalam aktivitas organisasinya. Berbeda dari wirausaha-wirausaha bisnis lainnya, menurut Dees perbedaannya terlihat pada misi mereka yang explisit dan central, hal ini tentunya mempengaruhi bagaimana socio entrepreneurs memandang serta menilai setiap kesempatan yang ada. ${ }^{12}$

Beberapa peneliti menyatakan bahwa misi sosial inilah yang menjadi dimensi utama dari sosial entrepreneurship. Ditambahkan lagi oleh Dees sama halnya dengan perusahaan bisnis yang mempunyai tujuan menciptakan nilai yang unggul untuk pelanggannya, tujuan utama dari socio entrepreneur adalah menciptakan nilai sosial yang mulia untuk pelanggan mereka. ${ }^{13}$ Kemampuan seorang pengusaha untuk mendapatkan sumber daya seperti modal, tenaga kerja, peralatan, dan lainnya dalam persaingan pasar adalah menunjukkan indikasi yang baik dari berjalannya suatu usaha yang produktif, sedangkan disisi lain seorang socio entrepreneur mencari cara yang inovatif untuk memastikan bahwa usahanya akan memiliki akses terhadap sumber daya yang dibutuhkan selama mereka dapat menciptakan nilai sosial. $^{14}$

\section{Pembahasan}

\section{Spiritual Entrepreneurship}

Kekuasaan gereja pada waktu itu benar-benar duniawi. Kapitalisme tanpa iman dan pelayanan sosial merasuk dan telah merusak dalam kehidupan gereja. Praktek-praktek spiritualitas perlahan-lahan tersingkirkan dan dikomersialkan, sehingga terjadinya reformasi memunculnya ambiguitas dalam persepsi pelayanan sosial, spiritual dan komersial berkembang dalam kehidupan bergereja sampai sekarang. Dietrich Bonhoeffer (1906-1945), seorang doktor teologi dan pendeta gereja Luteran (Protestan) menentang kekejaman Nazi dengan membangkitkan semangat saling menopang diantara orang beriman untuk memperbaharui kehidupan dunia yang "seakan-akan tiada Allah" sekalipun harus membayar

\footnotetext{
${ }^{10}$ Ibid.

${ }^{11}$ A. Nichollss, "Playing the Field: A New Approach to the Meaning of Social Entrepreneur," Social Enterprise Journal 2, no. 1 (2006): 1-5.

${ }^{12}$ G.S. Mort and J. Weerawardena, "Socio Entrepreneurship: Toward Conceptualisation," International Journal of Nonprofit and Voluntary Sector Marketing 8, no. 1 (2003).

${ }^{13}$ Ibid.

${ }^{14}$ Ibid.
} 
harga sebagai pengikut Yesus. Thomas Merton (1915-1968) adalah seorang anggota Komunitas Trappist di Kentucky, Amerika Serikat muncul dengan corak spiritualitas dengan melihat bagaimana orang Kristiani dapat mengalami Allah bukan di tengah kesunyian, melainkan di tengah keramaian dunia.

Sedangkan Roger L. Schutz dengan ke tujuh temannya membangun Komunitas Taize disebuah desa kecil di Cluny, Prancis tahun 1949. Komunitas Taize mengalami perkembangan dan kini merupakan sebuah komunitas oikumene. Inti spiritualitas Taize adalah menjadi ragi bagi perdamaian yang ditaburkan pada ribuan kaum muda yang melakukan penziarahan iman di Taize setiap tahunnya dan pertemuan-pertemuan dibelahan dunia. Semangat perdamaian Komunitas Taize merupakan "Perumpamaan Persatuan" ( $A$ Parable of Community).

Luther membangun Spiritualitas Protestan yang berintikan pembenaran (justification) hanya karena iman yang didasarkan pada Alkitab dan kehidupan Kristen. Bagi Luter Keselamatan hanya diperoleh melalui: Sola Gratia (hanya oleh anugerah), Sola Fide (hanya oleh iman), dan Sola Scriptura (hanya oleh firman). Disinilah terjadi pembaharuan di dalam ajaran dimana Luther meletakan dasar teologis spiritualitas kaum awam berupa imamat am (ke-imam-am yang tidak hanya pada kaum klerus-rohaniwan, tapi juga oleh setiap orang beriman kepada Yesus). Sedangkan Calvin mereformasi praktik kehidupan gereja dan masyarakat. Ia menolak disiplin spiritual seperti ziarah, puasa dan asketis. Kesalehan bagi Calvin adalah dengan menaati hukum Tuhan dan mengasihi sesama manusia. Dengan demikian, panggilan hidup kekristenan adalah bekerja, dan bukan melarikan diri dari dunia. Jhon Wesley, tokoh Gereja Methodist, memiliki corak spiritualitas sendiri dengan menekankan pada kesalehan pribadi serta pengudusan hidup Roh Kudus dan melakukan pelayanan sosial. Dengan adanya reformasi yang dilakukan oleh Luter dalam hal ajaran gereja dan Calvin dalam praktik kehidupan gereja dan masyarakat, telah memberikan ruang yang seluas-luasnya kepada kaum awan untuk beraktivitas.

Mencari Tuhan bukan saja di biara/geraja tapi juga dalam aktivitas ditempat bekerja sebagai panggilan hidup dan dalam melakukan pelayanan sosial (Social entrepreneur). Munculnya komunitas spiritual memberikan gambaran bagi kita tentang cikal bakal bagi entrepreneur dan entrepreneurship Kristen untuk berkembang dari abad ke abad dengan motif yang berbeda-beda. Spiritualitas telah membentuk entrepreneur dan entrepreneurship Kristen dalam bidang usaha dan kerja masing-masing. Sehingga muncul apa yang disebut spiritual kapitalisme yang harus menjadi dasar atau spirit bagi setiap entrepreneur yang mengarahkan dan menuntut kepada prilaku entrepreneurial, sehingga orang menjadi "consious" akan madatnya.

Penggambaran tentang spiritual entrepreneur Kristen adalah seorang/sekelompok orang (rohaniawan/umat Kristen) yang diberi mandat dan tugas untuk melakukan pekerjaan yang kreatif dan inovatif, dengan mengkombinasikan berbagai fungsi dan peran sebagai penemu, perencana, arsitek, manajer, administrator, pekerja, dan penyelia untuk mencipta sesuatu yang tidak ada menjadi ada dengan menggunakan sumber daya yang tersedia dan terbatas, berani 
menanggung resiko apapun dengan berlandaskan pada spirit of Jesus dalam mencari dan menemukan wajah Allah di tengah-tengah realitas hidup yang penuh tantangan.

Dari penelusuran ditemukan bahwa kata entrepreneur atau entrepreneurship telah ada dan berkembang ditengah-tengah kehidupan orang Kristen mulai dari abad 1 dan mendapat legitimasi/pengakuannya pada abad 14 untuk menggambarkan para klerus (rohaniwan). Stevens Paul (2008:218) dalam tulisannya tentang entrepreneur menjelaskan bahwa; pada abad ke 14 (abad pertengahan) telah ditemukan istilah/bentuk awal kata entrepreneur dari bahasa Perancis entreprendeur.

Penggambaran tentang entrepreneur entrepreneurship, dimana spiritualitas Kristen sebagai akar dari kehidupan beragama seseorang dimana melaluinya seseorang punya pengalaman atau keinginan mengenal Tuhan dengan caranya sendiri-sendiri akhirnya memunculkan bukan saja spiritual preneurship Kristen tapi juga entrepreneurentrepreneurship Kristen yang bergerak di berbagai bidang kehidupan (Sosial-EkonomiIntitusional-Ekologi) yang dapat mengubah dunia serta pola berfikir orang.

\section{Transformasi Diakonia dan Kemajemukan}

Majemuk berarti beda agama, budaya dan gaya hidup. Semuanya tidak akan pernah menjadi satu, tetapi harus saling membuka diri terhadap masalah bersama dari sudut pandang masing-masing. Muara dari keterbukaan ini adalah pembentukan etika, moral dan spiritual masyarakat yang plural itu. Agama lahir melalui proses pergumulan manusia dalam kehidupannya dengan yang ilahi. Seorang sosiolog asal Prancis, Emile Durkheim, mengatakan bahwa agama merupakan kekuatan yang amat memengaruhi sikap hidup manusia secara individual maupun sosial dan seharusnya menjadi perekat sosial yang kuat dalam kehidupan manusia.

Banawiratma mengatakan bahwa agama bukan hanya ajaran teoretis, merumuskan iman dan mengarahkan perilaku orang beriman, melainkan juga di dalamnya terdapat norma dan aturan, perintah dan larangan yang berkenaan dengan etika dan moral masyarakat. Semua agama bertemu pada titik ini: etika dan moral. Agama membangun peradaban manusia ke arah yang lebih baik. Cita-cita untuk mewujudkan peradaban manusia yang lebih baik itu dapat terjadi ketika manusia menghargai dirinya dan sesamanya. ${ }^{15}$

Spiritualitas berakar dari Yudaisme (kepercayaan dan tradisi orang Yahudi yang bersumber dari kitab-kitab Musa atau Torat dan kitab para nabi) yang didalamnya mengandung perjanjian, peringatan, dan berkat Allah. Adanya keyakinan bahwa Allah menyapa umatnya melalui kehadiran yang tersembunyi karena keterbatasan manusia memahami misteri ilahi, namun juga terwujud melalui kebijaksanaan (wisdom) di dalam kitab-kitab suci.

Sebagai upaya menyelami misteri ilahi dan mengerti kebijaksanaan yang dari Allah, maka orang mempraktikan melalui doa, nyayian, dan ibadah secara komunal di Bait Allah atau sinagoge. Pada satu sisi, Allah dapat dipahami, namun pada sisi yang lain, Allah tetap

\footnotetext{
${ }^{15}$ Ibid.
} 
misteri. Dalam perkembangan kekristenan spiritualitas dihayati melalui baptisan dan sakramen Perjamuan Kudus. Semangat untuk menghayati hidup bertapa di padang gurun pada abad-abad ini sangat kuat sekalipun bukan cara hidup orang kebanyakan. Kehidupan bertapa pada abad ini menjadi cikal bakal lahirnya biara-biara.

Manusia meyakini bahwa Allah menyapa manusia dengan caraNya tersendiri. Manusia terbatas dalam memahami misteri ilahi karena itu ada cara/praktek-praktek yang di lakukan sebagai "perantara" untuk mengantar manusia mengenal Allah. Semangat untuk menghayati hidup dengan cara bertapa adalah media/sarana tapi juga modal spiritual bagi orang-orang tertentu untuk mempersiapkan diri menjadi "perantara" untuk memperkenalkan Allah dalam realitas hidup yang ditemui lewat tugas dan kerja. Biara adalah salah satu aset spiritual. Para "perantara" di dalam biara selain memiliki aset spiritual memiliki juga aset intelektual. "Perantara" inilah yang oleh peneliti disebut entreprendre atau entrepreneur dalam bahasa Perancis.

Pada era ini spiritualitas Kristiani mengalami perkembangan yang berkesinambungan dengan berpijak pada pendalaman Alkitab dan penghayatan spiritualitas dari dalam biara bagi kehidupan secara luas. Penghayatan spiritualitas tersebut adalah seperti kerendahan hati, askese, dan relasi intim dengan Allah. Allah yang tetap misteri digambarkan sebagai "cahaya" oleh Gregorius Agung. Spiritualitas tidak dilihat sebagai hubungan dengan Allah semata, tetapi juga kepedulian kepada sesama. Salah satu latihan spiritual yang muncul pada era ini dalam tradisi hidup membiara adalah metode membaca dan berdoa dengan Alkitab yang memiliki empat tahap yang disebut lectio divina, yaitu lectio (membaca), oratio (doa lisan), meditatio (meditasi), dan contemplatio (kontemplasi).

Dengan berpijak pada Alkitab dan berakar pada spiritual telah membentuk serangkaian kegiatan yang berupa latihan spiritual untuk mencari Tuhan dan melakukan kegiatan sosial (volunter/sukarela) kepada sesama manusia. Dari penjelasan ini maka peneliti memunculkan latihan kegiatan-kegiatan sosial sebagai bagian dari socialpreneurship. Latihan spiritual sebagai bagian dari jenis kegiatan Spiritual preneurship dengan biara sebagai pusat pelatihan.

\section{Gereja sebagai Entrepreneurship Sosial}

Gereja adalah suatu lembaga yang konkret dan kelihatan. Gereja tidak sama dengan lembaga-lembaga di dunia karena merupakan persekutuan orang percaya. Dalam terjemahan sebelumnya disebut ekklesia. Artinya, dipanggil keluar dari dunia mereka yang lama dan dikuduskan atau diasingkan. Gereja masa kini harus senantiasa membaharui diri guna memenuhi kebutuhan anggotanya dan sebagai jawaban atas tugas dan panggilannya.

Pengutusan geraja ke dalam dunia mendatangkan konsekuensi bahwa gereja tidak hidup bagi dirinya sendiri, tetapi juga bagi lingkungan di sekitarnya. Gereja harus menghadapi berbagai tantangan dengan sikap kritis. Dalam Dokumen Keesaan Gereja PGI, gereja-gereja di Indonesia memahami bahwa negara adalah alat dalam tangan Tuhan yang bertujuan untuk menyejahterakan manusia dan memelihara ciptaan Allah. Kehadiran gereja-gereja di Indonesia merupakan tanda pengutusan Tuhan untuk mengambil bagian dalam mewujudkan perdamaian, keadilan, dan keutuhan ciptaan-Nya (bnd. Yer. 29:7). 
Sekarang ini, khususnya gereja-gereja di Indonesia, di tengah persoalan kemiskinan yang cukup akut, dan relasi dengan agama-agama lain, diakonia yang hanya bercorak kasih saja (dengan cara memberi) dirasa tidak cukup. Perlu ada pendekatan lain, yang mampu membangkitkan semangat kemandirian. Berdirinya beberapa yayasan atau kelompok di gereja mungkin akan melengkapi pendekatan diakonia kasih. Namun, kalau hanya menekankan pada pengembangan sikap mandiri, tetapi kurang mampu mengembangkan keberlanjutan juga dirasa kurang sempurna.

Berdasarkan pemikiran itu, pendekatan sosial entrepreneur dalam diakonia dirasa penting. Sosial entrepreneur merupakan cara melakukan perubahan (transformasi) sosial dengan prinsip-prinsip wira usaha sosial. Namun, berbeda dengan bisnis komersial yang senantiasa mengejar keuntungan dan pengembalian, social entrepreneur justru fokusnya adalah terciptanya modal sosial yang mencakup hubungan sosial, kepercayaan, kerja sama, sehingga dengan itu persoalan sosial bisa diatasi secara bersama.

Dengan kata lain, sosial entrepreneur adalah sebuah cara melakukan transformasi sosial yang modalnya, pola pengerjaannya, dampak dan keuntungannya "terbagi" kepada semua pihak yang terlibat di dalamnya. Sosial entrepreneur adalah proses pemberdayaan yang mengintegrasikan kekuatan semua pihak dalam masyarakat dan pasar secara bersama dan berkelanjutan. Melalui pendekatan social entrepreneur ini, diakonia mencakup bukan hanya soal bagaimana memperjuangkan hak-hak minoritas, baik dalam bidang sosial (budaya)politik-ekonomi, tetapi juga kewajiban orang kaya untuk terlibat dalam permasalahan sosial tanpa harus merasa dirugikan.

Diakonia dengan pendekatan semacam ini berusaha membangun "jembatan" antara mereka yang bergelut dalam bidang produksi dan konsumsi secara bersama tanpa harus merasa yang satu lebih tinggi dari yang lain. Produksi dan konsumsi di sini bukan sekadar yang bersifat nyata dan konkrit, tetapi juga soal makna dan kreativitas lainnya dalam konteks hidup bermasyarakat. Melalui diakonia seperti itu, gerakan ekumenis bisa dikembangkan dengan baik. Artinya, diakonia berbasis sosial entrepreneur dengan sendirinya keluar dari kungkungan primordialisma dan mengembangkan kehidupan bersama dengan semua orang tanpa dibatasi sekat-sekat sosial-politik yang ada.

Dengan demikian, diakonia gereja bukanlah kegiatan atau gerakan yang berdimensi santunan sosial berdasarkan agama; melainkan sebagai tugas agama atau gereja dalam memberi tanggapan atas persoalan masyarakat sebagai bukti dari iman dan ibadahnya kepada Tuhan; sekaligus dengan diakonia itu karya dan kasih Tuhan dinyatakan (marturia). Tujuan diakonia bukanlah menambah jumlah pengikut, tetapi meningkatkan kualitas hidup manusia (dan lingkungan) sebagai tempat pemeliharaan Tuhan berlangsung. Diakonia bukan untuk tujuan di luar kehidupan (sorga) tetapi untuk kehidupan sekarang yang mendesak.

\section{Kesimpulan}

Diakonia sosial sangat bermakna dan perlu, seperti pernah ditempuh oleh Paulus ketika mengumpulkan dana persembahan jemaat Korintus untuk menolong jemaat di Yerusalem (2 Kor. 8). Melalui konsep seperti itu akan tumbuh bela rasa (solidaritas) antara satu jemaat 
dengan yang lain. Namun, untuk konteks Indonesia, diakonia yang berpusat pada jemaat saja akan memicu perselisihan. Demikian juga diakonia yang terarah keluar tanpa sikap kritis menjadi alat bagi stigma Kristenisasi yang juga problematik bagi gereja di Indonesia. Karena itu untuk menjawab persoalan dan juga daya hidup program diakonia, pendekatan social entrepreneur diperlukan. Pendekatan ini menekankan keberlanjutan program, keuntungan jangka panjang yang bisa dinikmati bersama, dan kerja sama dengan semua pihak.

Diakonia dengan pendekatan sosial entrepreneur memerlukan konsep berjejaring, membangun relasi, menjadi "jembatan" yang mampu mempertemukan antara pihak yang dilayani dengan yang melayani secara baik. Itu berarti komunikasi, berelasi harus menjadi karakter yang dimiliki oleh gereja. Seperti Yesus yang selalu "menyuarakan" suara kaum terpinggir, dan membangun relasi dengan semua pihak, demikian juga gereja yang hendak mengembangkan diakonia sosial mesti menempuh jalan itu. Socio entrepreneur memiliki tujuan menciptakan nilai sosial dalam gereja perlu mendapat dukungan berbagai pihak seperti pemerintah, swasta maupun akademisi. Socio entrepreneur sangat bermanfaat dan akan selalu dibutuhkan masyarakat luas dalam menanggulangi permasalahan sosial yang selama ini masih terkesan terabaikan. Melalui kegiatan socio entrepreneur diharapkan kesejahteraan jemaat baik dibidang ekonomi, pendidikan maupun kesehatan meningkat secara signifikan.

\section{Referensi}

Atu Bagus Wiguna. "Social Entrepreneur Dan Socio-Entrepreneur: Tinjau Dengan Perspektif Ekonomi Dan Sosial.” Jurnal Ilmiah (2013).

Darwin Lumbantobing. Teologi Di Pasar Bebas. Pematang Siantar: L. SAPA, 2010.

Donald Guthrie. Teologi Perjanjian Baru 3. Jakarta: BPK Gunung Mulia, 1996.

Febriana, Mariani. "IMPLEMENTASI KEPEDULIAN SOSIAL GEREJA UNTUK MENOLONG MERETAS ANGKA KEMISKINAN.” Jurnal Theologi Aletheia 16, no. 7 (2014): 45-69. http://sttaletheia.ac.id/wp-content/uploads/2014/10/Pietas-danCaritas.pdf.

Mort, G.S., and J. Weerawardena. "Socio Entrepreneurship: Toward Conceptualisation." International Journal of Nonprofit and Voluntary Sector Marketing 8, no. 1 (2003).

Nanuru, Ricardo F, and Lomas Beatris Limpong. "Lomas Beatris Limpong 2." Jurnal UNIERA 3, no. 1 (2014): 51-60.

Nichollss, A. "Playing the Field: A New Approach to the Meaning of Social Entrepreneur." Social Enterprise Journal 2, no. 1 (2006): 1-5.

Soesilo, Yushak. "Pentakostalisme Dan Aksi Sosial: Analisis Struktural Kisah Para Rasul 2 : 41-47." Dunamis : Jurnal Teologi dan Pendidikan Kristiani 2, no. 2 (2018): 136-151. http://sttintheos.ac.id/e-journal/index.php/dunamis/article/view/172/134.

Tan, Wee-Liang, John Williams, and Teck-Meng Tan. "Defining 'Social' in Social Entrepreneurship: Altruism and Entrepreneurship." International Entrepreneurship and Management Journal (2005): 353-365.

World Council Of Churches. Iman Sesamaku Dan Imanku. Jakarta: BPK Gunung Mulia, n.d. Zega, Sabaria. "Pentingnya Memahami Entrepreneurship Secara Biblikal Bagi Hamba Tuhan.” KHARISMATA: Jurnal Teologi Pantekosta 1, no. 2 (2019): 118-132. http://www.stajember.ac.id/index.php/kharismata. 